\title{
Akulturasi Islam dalam Perkawinan Adat Dayak Ngaju: Sejarah Masyarakat Muslim di Desa Petak Bahandang, Kabupaten Katingan, Kalimantan Tengah
}

\author{
Noriani ${ }^{\mathrm{a}, 1, *}$, Abubakar $\mathrm{HM}^{\mathrm{b}, 2, *}$, Muhammad Iqbal ${ }^{\mathrm{c}, 3}$
}

${ }^{a}$ Institut Agama Islam Negeri Palangka Raya, Kalimantan Tengah, 73111, Indonesia

${ }^{b}$ Institut Agama Islam Negeri Palangka Raya, Kalimantan Tengah, 73111, Indonesia

'Institut Agama Islam Negeri Palangka Raya, Kalimantan Tengah, 73111, Indonesia

Inorianiasyifa@gmail.com*; 2 abubakar.hm@iain-palangkaraya.ac.id*;3 m.iqbal@iain-palangkaraya.ac.id

ARTICLE INFO

Article history:

Received : 2019-10-31

Revised : 2019-12-02

Accepted : 2019-12-21

Keywords:

Marriage

Dayak Ngaju

Acculturation
Kata Kunci:

Perkawinan

Dayak Ngaju

Akulturasi

\section{ABSTRACT}

Islamic acculturation in traditional Ngaju Dayak marriage: History of Muslim communities in Petak Bahandang Village, Katingan Regency, Central Kalimantan. There are three main issues to be discussed in this paper, namely how is the history of the village, how is the history and procession of traditional marriages and how is the acculturation of Islamic values and local culture in traditional marriages carried out by the Dayak Ngaju ethnic Muslim community. This article uses a type of historiographic research using a spoken history approach. The findings concluded that the Muslim community of Dayak Ngaju in Katingan Regency, Central Kalimantan Province, is still carrying out customary marriages. For them, the purpose of carrying out a traditional marriage is not as a symbol of the validity of a marriage relationship, but to preserve local wisdom and is a prevention of divorce by making an agreement. Muslim communities still have to fulfill the path of hadat drawn from the maternal lineage and in the procession the Muslim community first conducts a marriage according to religion. After that, they conduct a marriage according to the custom. This custom marriage represents Islamic values.

\section{ABSTRAK}

Akulturasi Islam dalam perkawinan adat Dayak Ngaju: Sejarah masyarakat muslim di Desa Petak Bahandang, Kabupaten Katingan, Kalimantan Tengah. Pokok masalah yang akan dibahas dalam tulisan ini ada tiga, yaitu bagaimana sejarah desa, bagaimana sejarah dan prosesi perkawinan adat dan bagaimana akulturasi nilai Islam dan budaya lokal dalam perkawinan adat yang dilaksanakan oleh masyarakat muslim Etnik Dayak Ngaju. Artikel ini menggunakan jenis penelitian historiografi dengan menggunakan pendekatan sejarah lisan. Hasil penelitian ini menyimpulkan bahwa masyarakat muslim Etnik Dayak Ngaju di Kabupaten Katingan Provinsi Kalimantan Tengah, hingga kini masih melaksanakan perkawinan secara adat. Bagi mereka tujuan melaksanakan perkawinan adat bukan sebagai simbol sahnya suatu hubungan perkawinan, tetapi untuk melestarikan kearifan lokal serta merupakan suatu pencegahan terjadinya perceraian dengan adanya pembuatan surat perjanjian. Masyarakat muslim tetap harus memenuhi jalan hadat yang ditarik dari garis keturunan pihak ibu dan dalam prosesinya masyarakat muslim terlebih dulu melaksanakan perkawinan secara agama baru kawin adat, tentunya perkawinan adat ini merepresentasikan nilai-nilai Islam.

\section{Pendahuluan}

Provinsi Kalimantan Tengah, lahir setelah kemerdekaan sebagai hasil proses dan dinamika politik yang demokratis pada masa Orde Lama, melalui perjuangan yang gigih dari masyarakat adat Dayak untuk memperoleh kemandirian (otonom) dalam rangka membangun daerahnya sendiri.(7) Etnik Dayak Ngaju memiliki kepercayaan yang disebut agama Helo atau 
Kaharingan.(2) Kaharingan adalah kebudayaan dan kepercayaan tradisional Etnik Dayak Ngaju di Kalimantan.(15) Demikian, bangsa Indonesia dikenal sebagai bangsa yang religius, yang kehidupan masyarakatnya kental dengan aktivitas dan semangat keagamaan.(6) Keberagaman etnik dan agama juga berpengaruh terhadap sistem perkawinan masyarakat Etnik Dayak Ngaju di Desa Petak Bahandang.

Masyarakat Etnik Dayak Ngaju, berpandangan bahwa perkawinan merupakan sesuatu yang luhur, suci dan terhormat.(19) Masuknya agama Islam di pedalaman Kalimantan Tengah dan banyaknya penganut Kaharingan berpindah ke agama tersebut, mengakibatkan terjadinya perubahan kebudayaan besar-besaran karena banyak unsur kebudayaan Dayak yang bersumber dari kepercayaan Kaharingan yang tidak dipakai lagi ketika penganutnya berpindah agama. Sekalipun masyarakat Dayak telah memeluk agama Islam, bukan berarti pengaruh tradisi lama dari kepercayaan agama helo sudah benar-benar hilang.(13) Hal tersebut dapat kita lihat pada masyarakat Muslim Etnik Dayak Ngaju di Desa Petak Bahandang yang masih melaksanakan upacara adat dalam prosesi perkawinan. Sehingga hal ini mengakibatkan terjadinya percampuran antara budaya Islam terhadap budaya lokal.

\section{Tinjauan Pustaka}

Prosesi perkawinan masyarakat Muslim Etnik Dayak Ngaju dan akulturasi Islam dan budaya lokal dalam prosesi perkawinan adat tentunya ada faktor yang mempengaruhi, yaitu: Teori Akulturasi. Teori Akulturasi merupakan konsep mengenai proses sosial yang timbul bila suatu kelompok manusia dengan suatu kebudayaan tertentu dihadapkan dengan unsur-unsur dari suatu kebudayaan asing dengan sedemikian rupa, sehingga unsur-unsur kebudayaan asing lambat laun diterima dan diolah dalam kebudayaan sendiri tanpa menyebabkan hilangnya kepribadian kebudayaan itu sendiri.(4) Konsep akulturasi Islam ini diposisikan sebagai kebudayaan asing dan masyarakat lokal sebagai penerima kebudayaan asing tersebut. Akulturasi timbul ketika kelompok-kelompok individu yang berbeda budaya berhubungan langsung dan sinambung, perubahan terjadi pada salah satu budaya asli atau kedua kelompok.(8)
Dalam mengkaji proses akulturasi ini, perlu diperhatikan beberapa hal yang terkait denga proses tersebut. Dimana menurut Koenjaraningrat ada 5 hal, Pertama, keadaan masyarakat penerima sebelum proses akulturasi mulai berjalan. Kedua, individuindividu yang membawa unsur kebudayaan asing itu. Ketiga, saluran-saluran yang dipakai oleh unsur kebudayaan asing untuk masuk ke dalam kebudayaan penerima. Keempat, Bagian-bagian masyarakat penerima terkena pengaruh unsur kebudayaan asing tadi. Kelima, Bagianbagian masyarakat penerima terkena pengaruh unsur kebudayaan asing tadi.(23)

\section{Metode Penelitian}

Penelitian ini menggunakan metode sejarah. Tujuan penelitian sejarah adalah untuk membuat rekonstruksi masa lampau secara sistematis dan objektif dengan cara mengumpulkan, mengevaluasi serta mensintesiskan bukti-bukti untuk menegakkan fakta dan memperoleh kesimpulan yang kuat.(17) Adapun sistematisasi proses penulisan dalam penelitian ini menggunakan heuristik dengan tujuan agar kerangka pemahaman yang didapatkan berdasarkan sumber-sumber yang relevan bisa disusun secara jelas, lengkap dan menyeluruh.(10) Suatu prinsip di dalam heuristik adalah seorang peneliti harus menggunakan pendekatan sejarah lisan untuk mendapatkan sumber yang disampaikan oleh saksi mata atau catatan record.(14) Setelah judul dan topik masalah dipilih, maka heuristik dilaksanakan dengan menghimpun jejak-jejak di masa lampau, yang berkaitan dengan perkawinan adat masyarakat Etnik Dayak Ngaju. Pengumpulan jejak-jejak ini dilakukan di Desa Petak Bahandang Kabupaten Katingan provinsi Kalimantan Tengah, dengan melalui teknik penentuan purposive sampling berdasarkan penilaian peneliti mengenai siapa saja yang pantas dan memenuhi persyaratan untuk dijadikan sampel sehingga mendapatkan data yang akurat. Sehubungan dengan ini dilakukan wawancara dengan para tokoh adat, tokoh agama, tokoh masyarakat dan para pelaku perkawinan adat. Selanjutnya dengan kritik sumber, merupakan langkah yang dilakukan untuk menyaring sumber-sumber yang telah dikumpulkan secara kritis agar terjaring fakta yang menjadi pilihan. Kritik sejarah 
dibedakan atas dua macam, yaitu kritik eksternal dan kritik internal.(12) Kritik eksternal berkaitan dengan autentisitas sumber. Autentisitas mencoba mencari jawaban terhadap keaslian dan keutuhan sumber yang dipakai. Selain dokumen, keaslian sumber lisan dalam penelitian ini harus dibuktikan keasliannya. Kritik internal berkaitan dengan kredibilitas sumber, yaitu menyangkut bisa tidaknya sumber tersebut dipercaya kebenarannya. Untuk proses penelitian ini, peneliti membandingkan datadata yang didapatkan berdasarkan pengamatan secara langsung akurat tidaknya informasi peristiwa yang disampaikan.

Interpretasi menjadi langkah selanjutnya dalam proses menganalisis sumber data, dimana menetapkan makna dan hubungan antar fakta dari sumber-sumber yang telah dikritisi. Juga historiografi, setelah semua tahapan telah dilalui maka historiografi merupakan kegiatan penulisan untuk menyampaikan sintesa atas penelitiannya yang telah dilakukan dan dapat dipertanggung jawabkan secara ilmiah menurut kaidah-kaidah yang telah ditentukan.(11)

\section{Hasil dan Diskusi}

\section{a. Prosesi Perkawinan Adat Masyarakat Muslim Etnik Dayak Ngaju di Kalimantan Tengah}

Sebelum adanya prosesi perkawinan adat masyarakat Muslim Etnik Dayak Ngaju, ada beberapa hal yang terkait dengan beberapa syarat benda-benda adat yang harus dipenuhi sebagai berikut:

\section{Garantung Kuluk Pelek}

Biasanya berbentuk sebuah gong sebagai bukti perjanjian perkawinan, dapat juga dinilai dengan uang atau emas. Pembayaran ini melambangkan tanggung jawab mempelai laki-laki atas segala perjanjian yang diikrarkannya didalam perkawinan tersebut. Makna simbolik garantung kolok pelek adalah: bahwa perkawinan dimulai dari kesepakatan bersama kedua pihak, berasal dari perasaan hati mereka yang mendalam, ada ikatan janji yang kuat baik lisan maupun tertulis, mengingatkan mereka supaya memelihara ikatan perkawinan, dan meluruskan arah hidup.

\section{Lamiang Turus Pelek}

Lamiang turus pelek sejenis manikmanik berwarna kemerah-merahan besarnya sebesar jari manis dan panjang antara 6-10 $\mathrm{cm}$. Makna simboliknya yaitu keteguhan ikrar janji kedua mempelai sejalan dengan kesepakatan-kesepakatan antara kedua mempelai, orangtua atau ahli waris serta kesepakatan menurut adat.

3. Bulau Singah Pelek

Bulau singah pelek melambangkan suatu ketulusan hati, kesungguhan yang keluar dari hati yang suci bahwa kedua mempelai wajib memelihara hubungan cinta kasih yang telah diikat melalui lembaga perkawinan. Sekarang, pemberian ini dapat berwujud cincin kawin, dan tidak dapat diganti dengan uang.

\section{Lapik Luang}

Lapik luang merupakan selembar kain panjang yang digunakan sebagai alas mangkok besar (sangku) peralatan haluang hapelek atau bisa berupa tikar rotan. Kain panjang ini melambangkan mempelai perempuan dalam menyambut kelahiran bayi dalam perkawinan itu. Sedangkan tikar sebagai alas duduk kedua mempelai ketika upacara adat nyaki palas.(3)

\section{Palaku}

Palaku merupakan suatu pembayaran yang ditujukan kepada mempelai perempuan, sebagai bukti ketulusan hati dari pihak mempelai laki-laki. Seiring perkembangan jaman palaku tidak hanya tanah, tetapi bisa berupa uang, emas, permata atau perhiasan lain. Adanya palaku karena dalam keluarga tersebut mereka menempatkan perempuan pada posisi paling utama, tetapi bukan berarti perempuan lebih berharga atau lebih berkuasa dari laki-laki.(5)

\section{Sinjang Entang}

Sinjang entang adalah pemberian kain sarung/bahalai oleh pihak laki-laki kepada orang tua perempuan. Kain tersebut sebagai simbol pengorbanan seorang ibu yang tulus memelihara anak perempuannya dari kecil hingga dewasa. Penyerahannya melambangkan rasa syukur, terima kasih serta mohon doa restu dari sang ibu mertua.

\section{Saput}

Saput berbentuk pemberian dari mempelai laki-laki untuk saudara lelaki dari si calon mempelai perempuan. Saput menyimbolkan rasa hormat, mengikat rasa persaudaraan yang tulus, bahwa mempelai 
laki-laki ingin dapat diterima menjadi bagian dari keluaraga calon mempelai perempuan. Pemberian saput dapat berupa barang maupun uang.

\section{Pakaian Sinde Mendeng/pakaian isek}

Sebagaimana halnya saput, pakaian sinde mendengadalah pemberian calon mempelai laki-laki kepada kakak adik perempuan dari calon mempelai perempuan. Ini menyimpulkan bahwa si mempelai lakilaki telah mengambil iparnya sebagai saudara kandungnya sendiri.

9. Tutup Uwan

Tutup uwan dari makna harfiah adalah penutup uban. Dilihat dari makna konstektual bahwa para orang tua masih sangat diperlukan sebagai tempat meminta perlindungan, doa restu, meminta pertimbangan, saran serta petunjuk. Dengan demikian, orang tua boleh saja rambutnya memutih namun nasihat, petunjuk dalam membina rumah tangga masih sangat diperlukan. Pemberian untuk nenek mempelai perempuan ini berbentuk dua yard kain hitam. Hal ini melambangkan bahwa mempelai laki-laki juga menerima nenek/kerabat istri sebagai nenek/kerabatnya sendiri.

\section{Lapik Ruji}

Lapik ruji adalah tempat menyimpan uang atau perhiasan lainnya yang terbuat dari kain. Makna simboliknya, bahwa rumah tangga baru itu mesti dimulai dengan adanya modal awal. Namun, sekarang bisa saja dengan memberi rekening tabungan.

\section{Timbuk Tangga}

Timbuk tangga adalah kebiasaan Etnik Dayak bilamana dilaksanakan perkawinan maka sanak saudara berdatangan. Mereka membantu membuat leladang (tenda), mengangkat kayu api, memperbaiki titian tangga, membersihkan halaman, dan lainlain. Timbuk tangga juga bantuan dana gotong royong dari pihak mempelai lelaki kepada pihak perempuan dapat berupa beras diisi dalam piring atau diganti uang ala kadarnya.

\section{Pinggan Pananan Pahinjean Kuman}

Pinggan pananan berupa pemberian peralatan rumah tangga seperti piring, mangkok, gelas dan lain-lain. Saat pesta perkawinan kedua mempelai diminta makan dan minum dalam satu wadah secara bersamaan. Hal demikian dilakukan untuk mengajarkan mereka selama hidup bersama dalam membangun rumah tangga tetap menyatu dengan segala perbedaan.

\section{Rapin Tuak}

Rapin tuak adalah minuman khas Dayak yang dibuat dari beras ketan yang dimasak dan diproses dengan ragi. Hasil permentasi ini menjadi minuman beralkohol. Tujuannya bukan untuk mabuk-mabukan, tetapi memperlancar bicara dan membuat semaraknya acara. Dapat disimpulkan bahwa adanya rapin tuak itu adalah diminum saat acara haluang sehingga memperlancar pembicaraan mereka.

\section{Bulau Ngandung/Panginan Jandau}

Panginan jandau adalah jamuan makan selama satu hari ketika pesta perkawinan. Biasanya orang Dayak mengundang masyarakat ramai untuk makan dengan gratis sebagai bentuk ucapan syukur terlaksananya perkawinan anak-anak mereka, biaya ditanggung bersama kedua belah pihak.

\section{Jangkut Amak}

Jangkut amak adalah tempat tidur pengantin disebut pelaminan atau isi kamar pengantin. Bisa berupa kasur, bantal, guling, seprei, kelambu serta pelaminan dan sebagainya. Biasanya ditanggung oleh kedua belah pihak.

\section{Turus Kawin}

Turus kawin adalah uang logam yang digunakan sebagai permohonan kesaksian dari para kerabat atau pengunjung yang menyaksikan pemenuhan hukum adat perkawinan. Karena jaman dahulu lebih lazim dengan perjanjian lisan, meskipun sekarang kesaksasian itu dimuat dalam surat perjanjian tertulis.

\section{Batu Kaja}

Batu kaja bisa berupa emas yang diberikan oleh orang tua dari mempelai lakilaki kepada menantunya. Melambangkan penerimaan dan kecintaan mertua. Biasanya diberikan ketika pelaksanaan pakaja manantu di rumah orangtua laki-laki.

Dari beberapa benda yang harus dimiliki oleh calon mempelai sebelum melakukan prosesi pernikahan adat yang dilakukan. Penjelasan tentang adanya tujuhbelas benda yang harus disiapkan ini diberlakukan manakala sebelum prosesi akad nikah berlangsung. Untuk melihat lebih mendalam bagaimana prosesi pernikahan adat yang notabenenya sudah mengalami 
akulturasi budaya antara Islam dan budaya lokal lain.

Prosesi perkawinan adat masyarakat Muslim Etnik Dayak Ngaju di Kalimantan Tengah sebagai berikut:

\section{Pra Perkawinan}

Tahapan pertama mempersunting seorang perempuan diawali dengan manyaluang atau penjajakan. Datangnya utusan pihak laki-laki ke perempuan dengan membawa selembar uang dan menanyakan apakah si perempuan sudah memiliki calon suami. Tahapan kedua, mamanggul dilakukan apabila lamaran sudah diterima oleh orangtua si perempuan dan dilakukan jika pelaksanaan perkawinan dalam jangka waktu yang lama. Maka keluarga pihak lakilaki akan datang untuk meminta si perempuan secara resmi memberikan tanda panggul berupa pakaian, alat kecantikan dan membuat perjanjian pertunangan. Tahapan ketiga, maja misek dilakukan jika waktu perkawinan relatif dekat. Pada pertemuan ini mereka membahas terkait jalan hadat yang harus dipenuhi oleh pihak laki-laki dan penentuan kapan perkawinan dilaksanakan.(9)

Setelah fase-fase peminangan telah dilalui dan penentuan waktu telah disepakati, maka nampaklah kegiatan-kegiatan dalam rangka persiapan menghadapi pelaksanaan perkawinan, antara lain marawei dengan mendatangi rumah-rumah seluruh sanak saudara untuk menyampaikan berita tentang perkawinan yang akan dilaksanakan. Sementara kegiatan-kegiatan lainnya pun dipersiapkan seperti timbuk tangga yakni bangunan tambahan di depan rumah mempelai perempuan. Sementara pihak perempuan lainnya baik keluarga, tetangga dan warga kampung ditugaskan membuat rarampah atau bumbu-bumbu bahan makanan yang dikerjakan secara gotong royong.

Pada malam menjelang hari akad nikah, kedua mempelai melakukan mandi batimung (sejenis mandi spa) dan pemakaian dawen pacar (daun pacar) dirumah masing-masing.
Batimung dilakukan oleh calon penganten untuk membersihkan atau mensucikan diri dari kotoran yang terdapat pada badan. Adapun tata cara batimung yaitu mula-mula disediakan air mendidih yang dimasukan dalam panci, calon pengantin dipersilahkan duduk dihadapan wadah dan kemudian ditutup mengeliling menggunakan tikar. Uapan air mendidih itu membuat berkeringat yang dipercaya dapat mensucikan diri seseorang. Selanjutnya pemakaian daun pacar yang ditumbuk sampai halus lalu ditempelkan pada kuku dan diikat menggunakan plastik hitam yang telah dipotong kecil. Tidak ada pemaknaan yang khusus dalam pemakaian daun pacar, hanya untuk memperindah penampilan calon pengantin ketika pelaksanaan perkawinan.

\section{Pelaksanaan Perkawinan}

Upacara perkawinan oleh masyarakat Muslim di Desa Petak Bahandang dilaksanakan dengan melalui dua prosesi. Prosesi pertama mereka melangsungkan perkawinan secara Islam dan prosesi kedua secara hukum adat. Prosesi acara akad nikah dilangsungkan menurut tuntunan ajaran Islam dan dipimpin oleh seorang penghulu dari Kantor Urusan Agama (KUA) setempat. Dalam pelaksanaan perkawinan masyarakat Muslim Desa Petak Bahandang tidak diwajibkan di KUA sehingga kebanyakan dari mereka melangsungkannya di rumah masing-masing. Sebelum akad nikah atau ijab qabul dilangsungkan, mempelai laki-laki dan perempuan, orang tua laki-laki, wali mempelai perempuan, dua saksi dari kedua bela pihak dihadirkan ditempat pelaksanaan akad nikah yang telah disiapkan.(22)

Seperti halnya adat perkawinan etnik bangsa lain yang menganut ajaran Islam, pelaksanaan akad nikah dilangsungkan berdasarkan urutan acara dimulai dari pembacaan ayat suci Alquran, penyerahan perwalian dari orang tua perempuan kepada penghulu untuk proses ijab kabul, acara khutbah nikah yang bertujuan untuk menyampaikan pesan dan nasihat kepada kedua mempelai agar mereka mampu membangun rumah tangga yang sejahtera, rukun dan damai, nasehat perkawinan biasanya disampaikan oleh seorang ustadz. 
Setelah itu, acara dilanjutkan dengan mempelai laki-laki duduk berhadapan seraya berjabat tangan dengan bimbingan penghulu mempelai pria mulai mengucapkan ijab kabul. Kalimat ijab kabul yang disampaikan oleh mempelai pria harus jelas kedengaran oleh para saksi untuk sahnya akad nikah. Oleh karena itu, tak jarang mempelai pria harus mengulanginya hingga dua sampai tiga kali. Kemudian penyerahan mas kawin dan pembacaan doa nikah serta pemeriksaan berkas perkawinan oleh penghulu dan penanda tanganan oleh kedua mempelai, dan wali.

Selanjutnya mempelai laki-laki dan perempuan mempersiapkan diri untuk kembali melaksanakan prosesi perkawinan secara adat. Perkawinan adat biasanya berlangsung setelah acara akad nikah atau esok harinya. Prosesi ini disebut panganten haguet yakni kedatangan mempelai laki-laki yang diarak (diantar) oleh sanak saudaranya menuju kediaman perempuan diiringi pembacaan shalawat dan bunyian habsy. Kemudian, acara penyerahan jalan hadat berupa benda-benda adat oleh ibu mempelai laki-laki kepada ibu mempelai perempuan. Satu persatu syarat benda adat itu diangkat untuk diperlihatkan kepada tamu undangan. Setelah itu kedua mempelai akan ditapung tawar oleh seorang Mantir Adat Islam. Tapung tawar merupakan sebuah ritual singkat yang dilakukan oleh tetua adat untuk memberikan doa keselamatan dan lain sebagainya dengan cara memercikkan air yang telah bercampur dengan minyak wangi ke atas kepala, kedua bahu, kedua telapak tangan dan kaki dengan membaca sholawat. Pada prosesi batapung tawar sebagian masyarakat melaksanakannya dengan menginjak batu dan mengoleskan sedikit telur pada kepala kedua mempelai.

\section{Pasca Perkawinan}

$\begin{array}{rrrr}\text { Orang } & \text { Dayak } & \text { Ngaju mempunyai } \\ \text { kebiasaan } & \text { bahwa } & \text { sesudah prosesi }\end{array}$ perkawinan, dilanjutkan acara mampakaja manantu. Pada acara inilah kedua mempelai kembali ditampung tawar dan orang tua mempelai laki-laki memberikan batu kaja bagi menantunya sebagai wujud kebahagiaannya menerima menantunya menjadi bagian dari keluarga. Orang tua mempelai laki-laki menyerahkan pakaian sinde mendeng dan uang atau perhiasan berupa emas murni sebagai batu kaja.(20) Masyarakat tidak diharuskan melaksanakan pakaja manantu karena prosesi ini hanya rangkaian tambahan yang kadangakala penyerahan batu kaja dan semacamnya sudah diberikan ketika pelaksanaan perkawinan berlangsung. Demikianlah tahapan adat yang telah diajarkan secara turun temurun oleh leluhur masyarakat Dayak Ngaju. Tahapantahapan adat ini masih dilaksanakan dan pelihara oleh masyarakat Muslim Etnik Dayak Ngaju di Desa Petak Bahandang sampai sekarang. Sekalipun mungkin jumlah, urutan dan sebutannya tidak sama, namun pada intinya hal itu menunjukkan bahwa perkawinan telah memenuhi hukum adat dan mereka siap menjalani kehidupan komunal.

\section{b. Akulturasi Islam dan Budaya Lokal di Desa Petah Bahandang}

Budaya lokal adalah suatu budaya yang berkembang di daerah-daerah dan merupakan milik etnik-etnik di Nusantara. Sedangkan budaya Islam adalah suatu cipta dan karya manusia baik Muslim maupun Non Muslim yang berangkat dari sumber ajaran Islam. Islam tersebar di tengah masyarakat dan terjadi interaksi di dalamnya antara budaya lokal dengan Islam.

\section{Hubungan akulturasi terjadi karena} adanya dua kekuatan yang saling mempengaruhi dan saling mewarnai satu sama lain. Dalam interaksi dua kebudayaan yang terjadi di Desa Petak Bahandang, berlanjut dengan adanya upaya modifikasi antara kedua kebudayaan, model semacam ini dalam istilah Gus Dur (Abdurrahman Wahid) dikenal dengan teori Pribumisasi Islam. Pribumisasi Islam adalah upaya mengokohkan kembali akar budaya dengan tetap menciptakan masyarakat yang taat beragama.(21) Hal ini adalah kebutuhan bukan untuk menghindari polarisasi antara agama dan budaya.(1)

\section{Manyaluang}

Tahapan awal mempersunting seorang perempuan di Desa Petak Bahandang di awali dengan datangnya utusan pihak lakilaki yang disebut luang menemui pihak perempuan. Utusan ini terlebih dulu 
menanyakan apakah si perempuan sudah memiliki calon suami karena dalam Islam terdapat larangan bagi seorang laki-laki melamar perempuan pinangan laki-laki lain. Sebagaimana salah satu hadits Nabi SAW sebagai berikut:

"Riwayat dari Abu Hurairah Nabi Muhammad Saw Bersabda: Janganlah seseorang dari kamu meminang (wanita) yang dipinang saudaranya, sehingga peminang sebelumnya meninggalkannya atau telah mengizinkannya". (Muttafaqun Alaihi).

Hadist Nabi diatas menjelaskan ketentuan tentang meminang perempuan yang telah dipinang sebagai berikut. Pertama, larangan meminang itu berlaku bila jelas-jelas pinangan pertama itu telah diterima dan dirinya mengetahui diterimannya pinangan tersebut. Kedua, larangan meminag berlaku bila peminang pertama itu adalah saudaranya yang seagama atau seorang Muslim. Ketiga, larangan itu tidak berlaku bila peminang pertama telah meninggalkan atau telah membatalkan pinangannya. Keempat, larangan itu juga tidak berlaku bila peminang pertama telah memberi izin kepada peminang kedua untuk mengajukan pinangan.

Pada tahapan ini pula seorang luang menyerahkan sejumlah uang sebagai bukti kesungguhan hati dari pihak laki-laki, terlebih dulu uang itu diterima oleh si perempuan untuk dimusyawarahkan bersama keluarganya. Ketika telah mendapat mufakat penerimaan lamaran maka uang itu digunakan untuk membeli bahan makanan sebagai jamuan di pertemuan keluarga kedua belah pihak selanjutnya. Diberikannya uang itu dapat membantu meringankan beban bagi pihak perempuan dan Islam selalu mengingatkan kaum Muslim untuk selalu berbuat kebaikan sesuai firman Allah swt

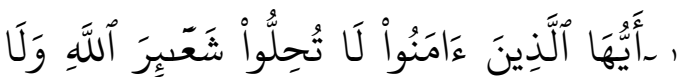

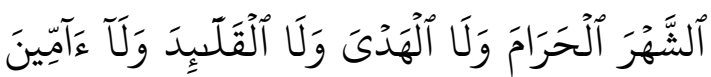

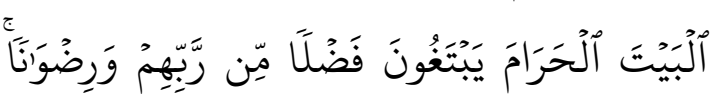

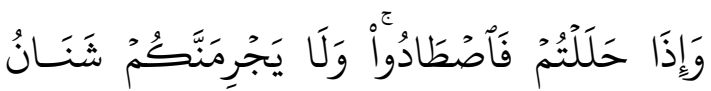

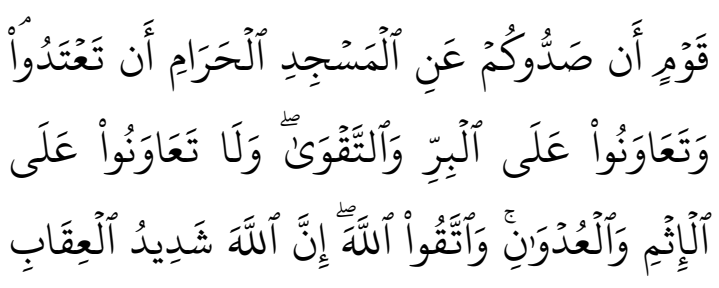

Artinya: Hai orang-orang yang beriman, janganlah kamu melanggar syi'ar-syi'ar Allah, dan jangan melanggar kehormatan bulan-bulan haram, jangan (mengganggu) binatang-binatang had-ya, dan binatangbinatang qalaa-id, dan jangan (pula) mengganggu orang-orang yang mengunjungi Baitullah sedang mereka mencari kurnia dan keridhaan dari Tuhannya dan apabila kamu telah menyelesaikan ibadah haji, maka bolehlah berburu. Dan janganlah sekali-kali kebencian (ти) kepada sesuatu kaum karena mereka menghalang-halangi kamu dari Masjidilharam, mendorongmu berbuat aniaya (kepada mereka). Dan tolongmenolonglah kamu dalam (mengerjakan) kebajikan dan takwa, dan jangan tolongmenolong dalam berbuat dosa dan pelanggaran. Dan bertakwalah kamu kepada Allah, sesungguhnya Allah amat berat siksaNya. (Q.S. Al-Maidah [5]:2)

\section{Mamanggul}

Apabila lamaran sudah diterima selanjutnya keluarga pihak laki-laki kembali datang untuk meminta si perempuan secara resmi. Islam mengajarkan apabila seorang laki-laki yang telah berketetapan hatinya untuk menikahi seorang perempuan, hendaknya meminang wanita tersebut kepada walinya. Tahapan mamanggul dilakukan jika pelaksanaan perkawinan dalam jangka waktu yang lama dan pihak laki-laki akan memberikan tanda panggul berupa pakaian, alat kecantikan dan lain sebagainya.

Kemudian kedua calon mempelai mengeluarkan duit turus meminta kesaksian dari sanak saudara yang hadir dan membuat perjanjian mamanggul. Menurut ajaran Islam memenuhi janji adalah wajib dan merupakan sifat orang-orang yang bertaqwa. Pada dasarnya dalam rangkaian acara ini terdapat prosesi nyaki palas seperti halnya masyarakat Dayak Ngaju Kaharingan, akan tetapi 
masyarakat muslim tidak melaksanakan ritual tersebut.(18)

\section{Maja misek}

Pada pertemuan ini keluarga kedua belah pihak mengambil kesepakatan bersama tentang kapan waktu pelaksanaan pesta perkawinan dan apa saja yang harus dipenuhi oleh pihak laki-laki sebagai syarat-syarat perkawinan (jalan hadat) serta yang berlaku baik menurut tradisi yang berlaku dalam keluarga calon mempelai perempuan. Jalan hadat ini meliputi besarnya palaku yaitu mas kawin yang harus diserahkan, biaya pesta perkawinan dan bagaimana pembagiannya, sanksi atau denda yang dikenakan jika terjadi pembatalan atau penundaan oleh salah satu pihak.

Kesepakatan mereka merupakan perjanjian yang kemudian dituangkan dalam surat perjanjian pisek. Pada tahapan ini terdapat kesamaan antara budaya lokal masyarakat Dayak Ngaju dan Islam dalam kewajiban memberikan mahar kepada mempelai perempuan yang tidak memberatkan bagi pihak laki-laki karena sebaik-baiknya perempuan adalah yang ringan maharnya serta melakukan suatu musyawarah yang dianjurkan dalam Islam sebagaimana firman Allah swt

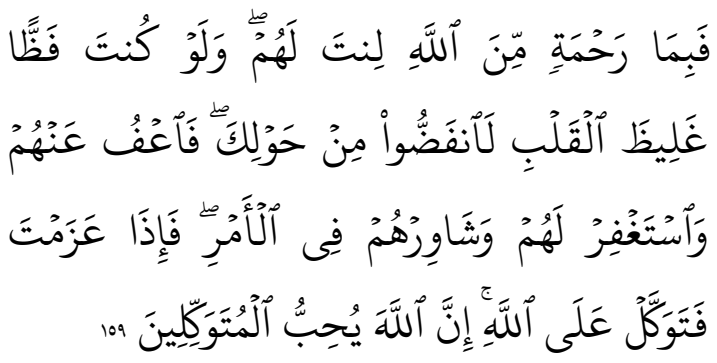

Artinya: Maka disebabkan rahmat dari Allah-lah kamu berlaku lemah lembut terhadap mereka. Sekiranya kamu bersikap keras lagi berhati kasar, tentulah mereka menjauhkan diri dari sekelilingmu. Karena itu maafkanlah mereka, mohonkanlah ampun bagi mereka, dan bermusyawaratlah dengan mereka dalam urusan itu. Kemudian apabila kamu telah membulatkan tekad, maka bertawakkallah kepada Allah. Sesungguhnya Allah menyukai orang-orang yang bertawakkal kepada-Nya. (Q.S. Ali-Imran [3]:159)

\section{Penganten Haguet}

Tahapan ini merupakan acara mempelai laki-laki saat berangkat menuju rumah mempelai perempuan sesuai dengan kesepakatan mengenai hari pelaksanaan perkawinan. Sebelum melakukan perjalanan itu mempelai laki-laki terlebih dahulu berkumpul bersama keluarganya untuk melaksanakan tampung tawar atau melakukan acara syukuran. Pihak kelurga mengantar putera mereka menuju tempat perkawinan seraya memainkan gendang habsy dan melantunkan sholawat. Dengan demikian suatu perkawinan adat itu mencerminkan nilai-nilai keislaman.(16)

\section{Mamapas}

Upacara ini adalah pembersihan secara simbolis bermakna agar penganten, rumah dan lingkungan tempat dilaksanakannya upacara perkawinan dapat bersih dari segala yang tidak baik dan terhindar dari hal-hal yang buruk yang ditimbulkan oleh roh-roh jahat yang disebut Pali Endus Dahiang Baya. Meskipun demikian, masyarakat Muslim Etnik Dayak Ngaju merasa tidak perlu melakukan ritual itu cukup dengan keyakinan dan membaca Bissmillah mereka masuk ke dalam rumah karena bagi mereka Allah swt maha pelindung. Sebagaimana firman Allah swt

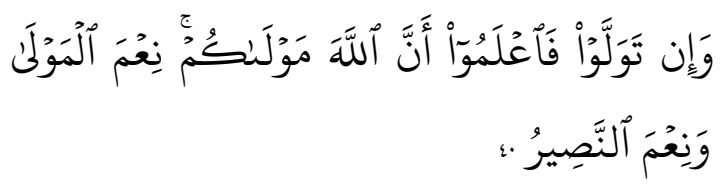

Artinya: Dan jika mereka berpaling, maka ketahuilah bahwasanya Allah Pelindungmu. Dia adalah sebaik-baik Pelindung dan sebaik-baik Penolong. (Q.S. Al-Anfal [8]:40)

\section{Nyaki Palas}

Inti upacara ini adalah pengukuhan perkawinan bagi masyarakat Kaharingan etnik Dayak Ngaju. Pada bagian inilah yang biasa tidak dilaksanakan oleh masyarakat Dayak Ngaju yang non Kaharingan terutama Islam. Ketika ritual ini berlangsung kedua mempelai duduk diatas gong/tikar sambil memegang sebatang pohon sawang yang diikat bersamaan dengan dereh uwei 
(sepotong rotan), rabayang (tombak bersayap/sejenis tri sula).

Jari telunjuk mereka menunjuk ke atas sebagai tanda bahwa mereka berdua bersaksi kepada Ranying Hatalla Langit serta kaki mereka menginjak batu asah sebagai tanda bahwa mereka berdua juga bersaksi kepada penguasa alam bawah seraya seorang Damang/Mantir mengoleskan darah hewan korban dan melakukan tampung tawar. Kemudian dilanjutkan dengan penanaman pohon sawang sebagai turus janji perkawinan mereka. Pada tahapan ini masyarakat Muslim Etnik Dayak Ngaju di Desa Petak Bahandang tidak melaksanakan sebagaimana mestinya dalam adat karena ritual nyaki palas melanggar ketentuan dalam Islam yang dianggap syirik. Sesuai firman Allah swt

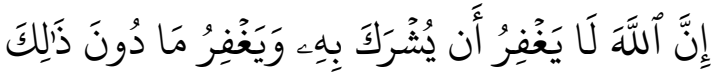

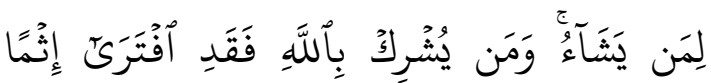

$$
\begin{aligned}
& \text { عَظِيمًا }
\end{aligned}
$$

Artinya: Sesungguhnya Allah tidak akan mengampuni dosa syirik, dan Dia mengampuni segala dosa yang selain dari (syirik) itu, bagi siapa yang dikehendakiNya. Barangsiapa yang mempersekutukan Allah, maka sungguh ia telah berbuat dosa yang besar. (Q.S. An-Nisa [4]:48)

Sehingga masyarakat hanya melakukan tampung tawar pada kedua mempelai diiringi puji-pujian pada Nabi Muhammad saw dengan membaca sholawat. Usai tampung tawar kedua mempelai bersama-sama membacakan surat perjanjian kawin yang isinya memuat syarat-syarat adat yang diserahkan yakni jalan hadat, sanksi-sanksi dan janji kedua mempelai dalam memelihara perkawinan dan memuat pula peneguhan para saksi dan ahli waris lalu ditandatangani. Selesai penandatanganan dilanjutkan dengan acara jamuan makan seperti walimah dalam Islam pada umumnya dan pemberian nasehat atau maningak panaganten bagi kedua mempelai dari orang tua.

\section{Pakaja Manantu}

Upacara ini merupakan penerimaan menantu oleh kedua orang tua mempelai lakilaki yang dilakukan dikediaman mereka.
Makna upacara ini merupakan ungkapan rasa syukur dan bahagia bahwa anak mereka sudah memiliki pasangan hidup. Ketika acara ini berlangsung orang tua laki-laki menyerahkan batu kaja bagian dari jalan hadat yang telah disepakati bersama dan kembali keduannya ditampung tawar seperti yang dilakukan sebelumnya. Dengan selesainya upacara pakaja manantu maka selesailah rangkaian upacara yang terkait dengan perkawinan adat Dayak Ngaju yang dilaksanakan oleh masyarakat Muslim di Desa Petak Bahandang.

Pada dasarnya percampuran budaya Islam dan budaya lokal yang terjadi dalam pelaksanaan perkawinan adat masyarakat muslim juga terlihat ketika penentuan hari pesta perkawinan, bergotong royong, marawei yakni datang ke setiap rumah untuk mengundang, membaca doa selamat sebagai pengganti puji-pujian atau mantra dalam adat, mengganti rapin tuak dengan meminum air biasa, membaca sholawat, adanya nasehat perkawinan dan lain sebagainya. Lebih dalam lagi nilai Islam jelas terlihat ketika masyarakat Muslim melaksanakan perkawinan secara Islam yakni akad nikah dengan deretan rangkaian acara yang menunjukkan keislaman dari pelakunya seperti pembacaan ayat suci Alqur'an, terdapat mahar berupa seperangkat alat sholat, pembacaan Istighfar, Syahadat, Sholawat dan terlihat pula dari busana yang digunakan oleh kedua mempelai.(22)

\section{Kesimpulan}

Masyarakat Muslim melakukan tahap lamaran seperti adat Etnik Dayak Ngaju setelah itu melaksanakan akad nikah di rumah maupun di KUA dengan memenuhi syarat dan rukun nikah. Biasanya pada malam menjelang hari akad nikah, kedua mempelai melakukan mandi batimung dan pemakaian dawen pacar.

Pelaksanaan akad nikah dilangsungkan berdasarkan urutan acara dimulai dari pembacaan ayat suci Alqur'an, Syahadat, Sholawat, Istighfar, penyerahan perwalian dari orang tua perempuan kepada penghulu untuk proses ijab kabul, dan acara khutbah nikah. Kemudian di hari yang sama atau keesokan harinya mereka melaksanakan 
kawin adat Dayak yang tidak dilaksanakan sebagaimana mestinya karena menyangkut keyakinan seperti meninggalkan prosesi yang berbau ritual yang tentunya melanggar ketentuan dalam Islam seperti ritual nyaki palas, mamapas dan penanaman pohon sawang.

Pada dasarnya percampuran budaya Islam dan budaya lokal dalam pelaksanaan perkawinan adat masyarakat Muslim terlihat ketika proses lamaran, penentuan hari pesta perkawinan, bergotong royong, marawei datang ke setiap rumah untuk mengundang, pesta perkawinan diawali dengan penganten haguet yakni mengantar mempelai laki-laki (diarak) diiringi gendangan habsy dan pembacaan Sholawat, dilanjutkan acara tampung tawar seperti pada umumnya lagilagi dengan Sholawat serta pembacaan surat perjanjian perkawinan adat, membaca doa selamat sebagai penganti puji-pujian/mantra dalam adat, mengganti rapin tuak dengan meminum air biasa, adanya nasehat perkawinan dan lain sebagainya serta kewajiban memberikan mahar.

Lebih dalam lagi nilai Islam jelas terlihat ketika masyarakat Muslim melaksanakan perkawinan secara Islam yakni akad nikah dengan deretan rangkaian acara yang menunjukkan keislaman dari pelakunya seperti adanya pembacaan ayat suci alQur'an, terdapat mahar berupa seperangkat alat sholat, pembacaan Istighfar, Syahadat, membaca Sholawat dan terlihat pula dari busana yang digunakan oleh kedua mempelai.

\section{Daftar Pustaka}

1. Basso A. Plesetan Lokalitas: Politik Pribumisasi Islam. Jakarta: Desantara, 2002.

2. Darmadi H. Dayak Asal-Usul dan Penyebarannya di Bumi Borneo. Sosial Horizon: Jurnal Pendidikan Sosial 3: 322-340, 2017.

3. HRD. Wawancara. 2019.

4. Karim A. Islam Nusantara. Yogyakarta: Pustaka Book, 2007.

5. KER. Wawancara. 2019.
6. Koentjaraningrat. Sejarah Antropologi I. Jakarta: Aksara Baru, 1982.

7. Mugeni A. Sumber Daya Alam dan Dimensi Sosial dan Kultural Masyarakat Adat Dayak di Provinsi Kalimantan Tengah [Online]. https://www.academia.edu/28302190/Su mber_Daya_Alam_dan_Dimensi_Sosial _dan_Kultural_Masyarakat_Adat_Dayak _di_Provinsi_Kalimantan_Tengah [28 Nov. 2019].

8. Mulyana D, Rakmat J. Komunikasi Antar Budaya. Bandung: PT. Remaja Rosdakarya, 2001.

9. MZP, SF. Wawancara. 2019.

10. Notosusanto N. Norma-Norma Dasar Penulisan dan Penelitian Sejarah. Jakarta: Pusat Sejarah ABRI, 1971.

11. Notosusanto N. Masalah Penelitian Sejarah Kontemporer. Jakarta: Yayasan Idayu, 1978.

12. Pranoto SW. Teori dan metodologi sejarah. Graha Ilmu, 2010.

13. Riwut T. Kalimantan Membangun; Alam dan Kebudayaan. Yogyakarta: PT. Tiara Wacana Yogya, 1993.

14. Samsuddin H. Metodologi Sejarah. Yogyakarta: Ombak, 2007.

15. Siyok D. Mutiara Isen Mulang: Memahami Bumi dan Manusia Palangka Raya. Palangka Raya: Khatulistiwa, 2014.

16. SPY. Wawancara. 2019.

17. Suryabrata S. Metodologi Pendidikan. Jakarta: Rajawali Press, 1983.

18. SYT. Wawancara. 2019.

19. Timotheus Tenggel Suan. Budaya Dayak: permasalahan dan alternatifnya: berdiri di kampung halaman memandang tanah air merangkul dunia. Bayumedia, 2011.

20. UA. Wawancara. 2019. 
21. Wahid A. Pergulatan Negara, Agama, dan Kebudayaan. Jakarta: Desantara, 2001.

22. WHD. Wawancara. 2019.

23. Yusuf M. Islam dan Budaya Lokal. Yogyakarta: Pukja Akademik UIN Suka, 2005. 